\title{
EVALUASI PENERAPAN GOOD CORPORATE GOVERNANCE PADA BANK PD BPR SARIMADU
}

\author{
Hastrid Sundari \\ Program Studi Magister Akuntansi Pasca Sarjana Fakultas Ekonomi \\ Universitas Riau \\ Email :hastridsundari12@yahoo.com
}

\begin{abstract}
This research is to see the application of the principles of good corporate governance in banks PD BPR Sarimadu, to investigate this issue, this research is using a descriptive method with a qualitative paradigm, while the data source are the primary data and secondary data. The sample was PD BPR Sarimadu. The results of this study demonstrate that PD BPR Bank Sarimadu are trying to create a business climate that is clean and healthy by trying to suppress the behavior of fraud on lending procedures that were implemented in the company by applying the principles of good corporate governance in the company's activities. From this study it can be concluded that there are an effect from applying the principles of good corporate governance on corporate performance. Since it first applied, this principles of good corporate governance so far managed to reduce the level of credit risk with a decreasing trend.
\end{abstract}

Keywords: Descriptive, primary data, secondary data, GCC

\section{PENDAHULUAN}

Dewasa ini usaha bank telah melenceng jauh dari hakikat dasarnya. Bank tidak lagi menjadi lembaga intermediasi atau penghubung antara orang kaya yang kelebihan dana dan pihak yang kekurangan dana. Perbankan juga lebih mementingkan keuntungan sesaat ketimbang menyalurkan kredit lebih banyak untuk kemakmuran bangsa. Per Oktober 2007, total dana masyarakat yang dihimpun perbankan nasional mencapai Rp. 1.419 triliun. Dana tersebut pada dasarnya merupakan milik dari individu atau institusi yang kelebihan uang. Dari total dana pihak ketiga (DPK) tersebut, ternyata yang disalurkan sebagai kredit hanya sekitar Rp. 937 triliun. Berarti, ada sekitar Rp. 482 triliun yang tidak diintermediasikan oleh bank, (Kompas November 2007).

Dengan berbagai macam alasan, perbankan malah menempatkan sebagian besar dana tersebut pada Sertifikat Bank Indonesia (SBI) sesuatu praktik yang sejatinya hanya menjadi beban bagi perekonomian negeri ini. Di satu sisi, banyak dana berlebih di negeri ini. Namun, pada saat bersamaan banyak pula orang yang menjadi miskin karena tak bisa meminjam modal untuk usaha. Fakta lain menunjukkan, perbankan merupakan salah satu industri dengan level keuntungan terbesar.

BPR didirikan berdasarkan UU No.7/1992 tentang Perbankan sebagaimana telah diubah dengan UU No.10/1998. Dalam UU tersebut secara tegas disebutkan bahwa BPR adalah Bank yang melaksanakan kegiatan usaha 
secara konvensional atau berdasarkan prinsip syariah yang dalam kegiatannya tidak memberikan jasa dalam lalu lintas pembayaran. Kegiatan usaha BPR terutama ditujukan untuk melayani usaha-usaha kecil dan masyarakat di daerah pedesaan. Bentuk hukum BPR dapat berupa Perseroan Terbatas, Perusahaan Daerah, atau Koperasi.

Perkembangan industri BPR saat ini Sangat pesat, seperti halnya di Propinsi Riau sudah terdapat sebanyak 27 unit BPR, dimana 6 BPR berbadan hukum sebagai Perusahaan Daerah dan 21 BPR berbadan hukum Perseroan Terbatas. Dari 27 unit BPR yang beroperasi di Propinsi Riau, Bank PD BPR Sarimadu merupakan salah satu BPR yang dimiliki oleh Pemerintah Kabupaten Kampar.

Berikut dapat dilihat kondisi keuangan pada Bank PD BPR Sarimadu selama tiga tahunterakhir yaitu dari tahun 2009 sampai tahun 2011.

Tabel 1: Perkembangan Kinerja BPR di Riau Tahun 2009-2011 (dalam Milyar Rupiah)

\begin{tabular}{clrrr}
\hline No & Pos Tertentu Neraca & $\mathbf{2 0 0 9}$ & $\mathbf{2 0 1 0}$ & $\mathbf{2 0 1 1}$ \\
\hline 1 & Total Asset & 6.731 & 7.474 & 8.680 \\
2 & Kredit yang diberikan & 4.619 & 4.860 & 7.663 \\
3 & Dana Pihak Ketiga & 3.082 & 4.280 & 6.526 \\
& $\quad-\quad$ Tabungan & 1.190 & 1.574 & 3.202 \\
& - Deposito & 1.892 & 2.706 & 4.124 \\
3 & Laba/Rugi Tahun Berjalan & 116 & 223 & 338 \\
4 & NPLS & $16 \%$ & $12 \%$ & $18 \%$ \\
5 & LDR & $75 \%$ & $71 \%$ & $67 \%$ \\
6 & ROA & $2.6 \%$ & $3.4 \%$ & $2.72 \%$ \\
\hline
\end{tabular}

Sumber : Laporan Keuangan Bank PD BPR Sarimadu

Dari Tabel 1 terlihat bahwa dalam pegelolaan Bank PD BPR Sarimadu ditemukan berbagai permasalahan, sehingga fungsi Bank PD BPR Sarimadu sebagai BPR belum dapat dilaksanakan secara optimal. Permasalahan yang dihadapi oleh Bank PD BPR Sarimadu selama ini diantaranya :

1. Tingginya nilai NPLs, yang mengindikasikan banyaknya kredit macet yang disalurkan oleh PT BPR di Propinsi Riau.

2. Permasalaham kedua adalah masih rendahnya nilai LDR yaitu berada dibahwa 80\%, sehingga mengindikasikan menurunnya jumlah tabungan masyarakat yang dapat disalurkan oleh pihak Bank PD BPR Sarimadu.

3. Rendahnya nilai ROA yang mengindikasikan rendahnya tingkat pengembalian asset dalam Bank PD BPR Sarimadu.

Permasalahan lainnya yang dihadapi dalam pengelolaan Bank PD BPR Sarimadu adalah dalam pengelolaan manajemen, seperti masalah kualitas SDM. Karena kebanyakan penerimaan karyawan pada Bank PD BPR Sarimadu yang tidak diumumkan, sehingga tingkat kompetensi karyawan rendah. Dan 
kebanyakan karyawan memiliki hubungan keluarga dari pemilik atau pemegang saham.

Sistem seleksi karyawan yang tidak transparan, maka mengakibatkan banyak karyawan yang tidak menguasai pekerjaannya dengan baik. Hal ini tentunya mengambarkan masih belum baiknya penerapan GCG dalam pengelolaan Bank PD BPR Sarimadu. Kemudian juga ditemui masih belum terealisasinya keadilan dan kesejahteraan dalam memenuhi hak-hak secara wajar dan kesetaraan antara karyawan dengan stakeholder. Hal ini terlihat dari besarnya kompensasi bagi para pimpinan pada Bank PD BPR Sarimadu dibandingkan dengan hasil yang diterima oleh pihak pemilik saham. Dimana para pimpinan perusahaan selalu memperoleh bonus akhir tahun yang jumlahnya sampai ratusan juta rupiah, sedangkan pihak pemilik saham hanya memperoleh persentasi keuntungan.

Melihat permasalahan tersebut maka diperlukan tata kelola yang baik (good corporate governance) dalam pengelolaan Bank PD BPR Sarimadu agar dapat menjaga kelangsungan (survive) demi meningkatkan kegiatan dan aktivitas dalam Bank PD BPR Sarimadu. Seperti permasalahan krisis perbankan di Indonesia yang dimulai pada akhir tahun 1997 bukan semata-mata diakibatkan oleh krisis ekonomi, tetapi juga di akibatkan oleh belum di implementasikannya good corporate governance dan etika yang melandasinya. Oleh karena itu, usaha mengembalikan kepercayaan kepada dunia perbankan Indonesia melalui restrukturisasi dan rekapitalisasi, hanya dapat mempunyai dampak jangka panjang apabila disertai tiga tindakan penting, yakni: (1) Ketaatan terhadap prinsip kehati-hatian ; (2) Pelaksanaan Good Corporate Governance; (3) Pengawasan yang efektif dari otorisasi pengawasan bank.

Oleh karena pelaksanaan Good Corporate Governance (GCG) sangat diperlukan untuk membangun kepercayaan masyarakat dan dunia internasional sebagai syarat mutlak bagi dunia perbankan untuk berkembang dengan baik dan sehat. Oleh karena itu ketaatan akan prinsip-prinsip Good Corporate Governance antara lain transparansi (transparency), kemandirian (independence), akuntabilitas (accountability), pertanggungjawaban (responsibility), dan kewajaran (fairness) dalam menjalankan perbankan dan segala prosedur yang ada didalamnya haruslah terlaksana dengan baik agar Bank PD BPR Sarimadu dapat berkembang dengan baik dan sehat.

Resiko dalam menjalankan aktivitas pada Bank PD BPR Sarimadu lebih komplek dari pada lembaga keuangan umum yaitu fluktuasi suku bunga, piutang gagal bayar, kesalahan operasional dan lain sebagaiya. Hal ini juga menuntut para pelaku bisnis keuangan pada Bank BPR Sarimadu lebih pruden, termasuk didalamnya pengawasan dan kontrol yang berfungsi baik. Disnilah perlunya peningkatan pelaksanaan GCG dalam industri. 


\section{METODE PENELITIAN}

\section{Desain Penelitian}

Metode penelitian yang digunakan dalam penelitian ini adalah metode deskriptif dengan paradigma kualitatif. Menurut Poewandari (1998) penelitian kualitatif adalah penelitian yang menghasilkan dan mengelola data yang sifatnya deskriptif, seperti transkripsi wawancara, catatan lapangan, gambar, foto, rekaman video dan lain-lain. Penelitian kualitatif menekankan pada pentingnya kedekatan dengan orang-orang dan situasi penelitian, agar peneliti memperoleh pemahaman jelas tentang realitas dan kondisi kehidupan nyata. (Burhan, 2010)

Penelitian ini bersifat deskriptif dalam menganalisa penerapan good corporate governance pada lembaga perbankan yaitu Bank PD BPR Sarimadu. Pemilihan studi ini dikarenakan penelitian kualitatif digunakan untuk mendeskripsikan interaksi dengan informan dan juga dapat memberikan informasi yang lebih mendalam. Desain ini cocok untuk menggali informasiinformasi yang melatar belakangi perilaku tertentu dan pendapat informan mengenai masalah tertentu.

Dalam penelitian ini peneliti ingin mengamati dan mengkaji data-data faktual tentang gambaran proses penerapan prinsip good corporate governance yang terjadi dilapangan, kemudian mendeskripsikan hasil temuan dilapangan kedalam bentuk tulisan. Dalam hal ini penulis berusaha untuk mengambil data dalam suasana yang wajar dan tanpa manipulasi/merekayasa sesuai situasi, sehingga data yang diperoleh akan memenuhi validasi data yang diperlukan. Upaya untuk memperoleh data yang valid dilakukan dengan menggali informasi setuntas mungkin dan mengambil data sesuai fokus kajian. Pelaporan data disusun dalam bentuk deskriptif kemudian peneliti menarik kesimpulan.

\section{Lokasi dan Subjek Penelitian}

Lokasi penelitian merupakan tempat dimana proses penelitian berlangsung. Peneliti berkeinginan untuk mengetahui tentang penerapan prinsip good corporate governance terhadap prosedur pemberian kredit pada salah satu lembaga perbankan di Indonesia. Penelitian ini dilaksanakaan di Kantor Pusat Bank PD BPR Sarimadu Bangkinang.

Informan penelitian dipilih berdasarkan atas pertimbangan atau kriteria tertentu dari peneliti, dengan harapan mendapatkan informasi sebanyak mungkin. Teknik ini dikenal dengan purposive sampling. Kriteria yang ditentukan oleh peneliti yaitu pihak berkompeten dan memiliki kewenangan dalam pengawasan penerapan good corporate governance dan telah berpengalaman lebih dari 2 tahun. Adapun yang menjadi responden dalam penelitian ini adalah komite audit, direktur utama, pemilik saham, komite kebijakan perkreditan, komite kredit, komite pertimbangan kasus kepegawaian, komite manajemen risiko 


\section{Jenis dan Sumber Data}

Jenis dan sumber data yang digunakan dalam penelitian ini adalah data primer dan data sekunder. Data primer adalah data yang diperoleh dari hasil wawancara atau intervine dengan pihak-pihak terkait. Dalam penelitian ini jenis data yang penulis gunakan adalah data subyek yaitu data berupa opini, sikap, pengalaman atau karakteristik dari seseorang atau sekelompok orang yang menjadi subyek penelitian.

Sedangkan data sekunder adalah data yang diperoleh dari instansi terakit, seperti data laporan keuangan, data kinerja bank yang dilihat dari kondisi finansial, sejarah berdirinya perusahaan dan data-data lainnya yang relevan dengan penelitian ini.

\section{Teknik Pengumpulan Data}

Dalam penelitian ini, penulis mengumpulkan data-data dengan menggunakan teknik-teknik pengumpulan data sebagai berikut :

1. Penelitian Lapangan (Field Research)

Penelitian ini bertujuan untuk mendapatkan data yang akurat mengenai gambaran umum perusahaan dan data-data yang relevan dengan subjek penelitian yang dilakukan. Adapun alat yang digunakan untuk mengumpulkan data dalam penelitian ini adalah :
a. Wawancara.
b. Pengamatan (Observasi).
c. Dokumentasi.

\section{Teknik Analisis Data}

Pengolahan data yang digunakan dalam penelitian ini adalah teknik analisis kualitatif maka dari itu penulis memiliki beberapa langkah dalam melakukan teknik analisis secara kualitatif yaitu :

1. Hasil dari penelitian berupa data kemudian disorting (mengolah informasi yang diperoleh sehingga sistematis berdasarkan variabel yang diteliti) dengan cara mereduksi data yang diperoleh. Proses reduksi data berarti merangkum, memilih, hal-hal yang pokok, memfokuskan pada hal-hal yang penting dan membuang yang tidak diperlukan.

2. Data kemudian disajikan dalam bentuk deskripsi, peneliti melakukan classifying (mengklasifikasikan informasi yang disusun sebelumnya agar dapat dibandingkan responden) dengan cara menyajikan data tersebut.

3. Penyajian diikuti dengan proses mengumpulkan data-data yang saling berhubungan satu sama lain melalui wawancara, pendokumentasian dan pengamatan yang lebih mendalam. Data-data yang saling berhubungan 
dikelompokan sehingga terbentuk kelompok-kelompok data yang selanjutnya akan disimpulkan.

4. Sedangkan untuk menganalisis data dipakai content analysis (teknik yang digunakan untuk menarik kesimpulan melalui usaha menemukan karakteristik pesan yang dilakukan secara objektif dan sistematis).

5. Setelah peneliti menarik kesimpulan dari hasil penelitian, kemudian meminta pertimbangan kepada berbagai pihak mengenai data-data yang diperoleh dari lapangan. Isi kesimpulan tersebut akan menyatakan kredibilitas dari asumsi awal yang ditentukan oleh peneliti.

\section{HASIL DAN PEMBAHASAN}

Dari hasil wawancara dengan pihak-pihak terkait dalam penelitian ini, diperoleh informasi mengenai penerapan prinsip-prinsip GCG pada Bank PD BPR Sarimadu sebagai berikut :

\section{a. Keterbukaan (Transparancy)}

Adapun implementasi penerapan prinsip ini adalah sebagaimana penulis uraikan terhadap beberapa pertanyaan yang berkaitan dengan transparancy yaitu pertanyaannya apakah perusahaan anda mengembangkan system akuntansi berdasarkan standar akuntansi?. Berdasarkan hasil wawancara dengan Direktur Utama Bapak Syafri pada Tanggal 22 September 2012 jam 09.30 WIB di kediaman yang berkedudukan Jalan Paus Pekanbaru, diketahui bahwa : (Apakah Bank PD BPR Sarimadu sudah mengembagkan system akuntansi yang sesuai dengan standar yang berlaku.

"Direktur Bank PD BPR mengatakan bahwa perusahaan yang dipimpinannya sudah mengembangkan sistem akuntansi yang berdasarkan pada standar akuntansi yang berlaku. Dan hal itu juga merupakan sudah standar dalam operasional BPR yang ditetapkan oleh Bank Indonesia, misalnya sistem pencatatan dalam buku tabungan, pelaporan, neraca dan lainnya"

Hal ini juga terlihat bahwa selama tahun 2011, Bank PD BPR Sarimadu sebagai lembaga perbankan perkreditan rakyat selalu melaksanakan kewajibannya, khususnya dalam menerapkan GCG serta menyampaikan laporannya kepada Bank Indonesia (BI). Menurut pengamatan saya selama penelitian, maka dijumpai bahwa bank ini sudah melakukan pengembangan sistem akuntansi yang dapat mendukung dan memperlancar aktivitas atau operasional bank sebagai mana yang diharapkan.

Kemudian hasil wawancara dengan pemegang saham yaitu Bp. Zulher yang saat ini telah menjadi kepala dinas perkebunan Provinsi Riau pertanyaannya tentang bagaimana pendapat anda tentang pelaksanakaan 
transfaransi saat ini diperusahaan BPR Sarimadu sewaktu anda menjadi Ketua dewan pengawas, maka ia mengatakan bahwa:

"Pelaksanaan prinsip transparancy di Bank PD BPR Sarimadu sudah terlaksana dengan baik jika diperhatikan dari pengembangan system nya sudah memadai dengan baik, dan pelaporan nya saya lihat telah disampaikan secara berkala”

Menurut saya, Hal ini juga terlihat transparansinya dimana Bank BPR telah mempublikasikan laporan tahunannya di Koran nasional.

Kemudian pertanyaan selanjutnya pada direktur utama adalah "Apakah perusahaan anda sudah mengungkapkan informasi secara tepat waktu, memadai, jelas, akurat dan dapat diperbandingkan". Dan hasil wawancara dengan direktur utama pada Tanggal 22 September 2012 Jam 9.30 di kediamannya Jalan Paus Pekanbaru, diketahui bahwa :

"Pelaporan yang tepat waktu dalam perbankan merupakan hal yang penting untuk dilaksanakan karena jika terlambat memberikan laporan pada BI akan berdampak tidak baik pada BPR, karena BI akan memberikan teguran pada pihak manajemen BPR yang bersangkutan”.

Hal ini sebagai wujud komitmen bank dalam melaksanakan ketentuan BI No. 8/4/PBI/2006 tanggal 30 Januari 2006 tentang Penerapan Good Corporate Governanace pada Bank Umum dan PBI No. 8/14/PBI/2006 tanggal 5 Oktober 2006 tentang Perubahan atas PBI No.8/4/PBI/2006 serta Surat Edaran Bank Indonesia (SEBI) No.9/12/DPNP tanggal 30 Mei 2007, khususnya Pasal 62 dan Pasal 63 mengenai kewajiban Bank menyampaikan laporan pelaksanaan GCG, baik secara tersendiri maupun digabungkan dalam laporan keuangan.

Hasil wawancara dengan Bapak Zulher pada Tanggal 25 September 2012 Jam 10.00 dikantor dinas Perkebunan Provinsi Riau, disini penulis ingin mengetahui bagaimana kondisi BPR Sarimadu dari segi pemegang saham yaitu mengenai ketepatan pelaporan yang dilakukan oleh manajemen Bank PD BPR Sarimadu selama bapak menjabat sebagai ketua dewan pengawas, diketahui bahwa : (Bagaimana ketepatan dalam memberikan laporan dari bawahan ke atasan.)

"Bank PD BPR Sarimadu memberikan laporan kepada para pemegang saham sering mengalami keterlambatan dari batas waktu yang ditetapkan, sehingga saya sewaktu menjabat merasa manajemen bank tersebut belum efektif dan efisien melaksanakan tugas dan fungsinya sebagai penggerak perusahaan".

Namun demikian untuk mendukung terlaksananya penerapan GCG di Bank PD BPR Sarimadu yang independen dan transparan, Bank PD BPR Sarimadu telah menunjuk pula konsultan, untuk melakukan review dan reassessment serta memberikan bahan masukan terhadap pelaksanaan penerapan GCG selama ini, sehingga ke depan diharapkan dapat menjadi lebih baik lagi. 
Selanjutnya juga ditanyakan "apakah perusahaan selalu melakukan Rapat Umum Pemegang Saham Tahunan (RUPST) dan Rapat Umum Pemegang Saham Luar Biasa (RUPSLB). Hasil wawancara dengan Direktur Utama di kediamannya pada Tanggal 22 September 2012 menjelaskan bahwa :

"Bank PD BPR Sarimadu selalu menyelengarakan Rapat Umum Pemagang Saham (RUPS) setiap akhir tahun, misalnya pada tahun 2012 Bank PD BPR Sarimadu telah menyelenggarakan Rapat Umum Pemegang Saham Tahunan (RUPST) dan Rapat Umum Pemegang Saham Luar Biasa (RUPSLB)” pada Bulan April 2012.

RUPST pada tanggal 23 April 2012 telah memberikan persetujuan dan menerima penuh pertanggungjawaban Direksi atas pencapaian kinerja perusahaan serta menyetujui laba yang diperoleh untuk dibagikan sesuai dengan persyaratan dan tata cara pembayaran dividen, disamping telah memberikan wewenang kepada Dewan Komisaris untuk mengangkat Akuntan Publik tahun buku 2011.

Selain itu dalam salah satu keputusan RUPSLB yang diselenggarakan pada tanggal 23 April 2012 tersebut, telah menyetujui dan memberikan wewenang serta kuasa kepada Direksi untuk melakukan perubahan dan penyempurnaan atas Anggaran Dasar Bank PD BPR Sarimadu, disesuaikan dengan ketentuan yang berlaku saat ini terutama peraturan Bank Indonesia seperti PBI tentang Penerapan GCG. Hal ini dapat dilihat dan sebagaimana yang tercantum dalam Salinan Akta Berita Acara RUPS Nomor 177 dan Akta Berita Acara RUPSLB Nomor 180 yang dibuat oleh Notaris Arry Supratno, SH.

Rencana strategis bank termuat dalam rencana jangka menengah/sedang dan rencana jangka panjang. Rencana jangka menengah/sedang Bank PD BPR Sarimadu tercantum dalam Rencana Bisnis Bank yang dikirimkan kepada Bank Indonesia setiap tahun. Sementara itu rencana jangka panjang tercantum dalam rencana korporasi (Corporate Plan). Kedua rencana tersebut disusun dengan mempertimbangkan faktor eksternal seperti kondisi makro dan mikro ekonomi domestik maupun internasional, industri perbankan nasional dan juga faktor internal seperti jumlah jaringan cabang, aliansi, produk dan jasa, sumber daya insani. Selain itu dalam rencana bisnis telah pula mempertimbangkan dampak yang mungkin terjadi yang disebabkan oleh krisis ekonomi global.

Rencana bisnis Bank PD BPR Sarimadu untuk tahun 2009 sampai 2012 telah disampaikan kepada BI pada bulan Januari 2009 dengan surat No.075/DIR/BSM/I/2009 tanggal 30 Januari 2009 sedangkan Rencana Korporat untuk tahun 2009 ssampai dengan 2014 telah pula dibuat. Adapun bentuk, isi dan format Rencana Bisnis maupun Corporate Plan telah mengacu kepada ketentuan Bank Indonesia sebagaimana di atur dalm PBI No.6/25/PBI/2004 tanggal 22 Oktober 2004 tentang Rencana Bisnis Bank Umum. 
Evaluasi terhadap realisasi anggaran atau rencana bisnis dilakukan baik oleh Dewan Pengawas maupun oleh Direksi Bank PD BPR Sarimadu secara berkala atau setiap 3 (tiga) bulan. Evaluasi oleh Komisaris tersebut merupakan salah satu pelaksanaan tugas pengawasan Komisaris dan laporan pengawasan dimaksud telah disampaikan kepada Bank Indonesia, sebagaimana yang diwajibkan.

Dilihat dari aspek tranparancy dari personalia, misalnya dalam hal penerimaan pegawai, sering dijumpai tidak terlaksananya prinsip transparency, misalnya penerimaan karyawan yang tidak dimumkan, menanggapi hal ini direktur utama dalam wawancaranya pada tanggal 22 September 2012 menjelaskan bahwa “

"Penerimaan karyawan pada Bank PD BPR Sarimadu untuk dua tahun terakhir sudah diumumkan dan sudah dilakukan seleksi dengan melalui beberapa tahapan, namun dalam pelaksanaannya memang masih adanya penekanan bahwa karyawan yang bersangkutan harus putra/i Kampar, walaupun hal ini tidak disebutkan dalam persyaratan".

Dengan memperhatikan tanggapan dari direktur utama tersebut, maka diketahui bahwa penerapan prinsip GCG dalam hal transparancy dibidang rekrutmen karyawan belum terlaksana dengan baik. Karena masih terdapatnya praktek-praktek penerimaan karyawan yang tidak transparan. Hal ini dilakukan karena mengingat bahwa Bank PD BPR Sarimadu merupakan perusahaan daerah yang memberikan kesempatan pada masyarakatnya untuk bekerja disana.

\section{a. Akuntabilitas (Accountability)}

Berdasarkan prinsip akuntabilitas ini, maka bank BPR PD Sarimadu harus menetapkan tanggung jawab yang jelas dari setiap komponen organisasi, selaras dengan visi, misi, sasaran usaha, dan strategi perusahaan. Setiap komponen organisasi mempunyai kompetensi sesuai dengan tanggung jawab masing-masing. Mereka harus dapat memahami perannya dalam pelaksanaan GCG.

Selain itu, bank harus memastikan ada dan tidaknya check and balance dalam pengelolaan bank. Bank harus memiliki ukuran kinerja dari semua jajarannya berdasarkan ukuran yang disepakati secara konsisten, sesuai dengan nilai perusahaaan (corporate values), sasaran usaha, strategi bank, serta memiliki reward and punishment system.

Dewan Komisaris bertindak atas nama pemegang saham, dan tugasnya adalah memantau dan mengawasi pelaksanaan tugas Direksi secara kolektif dalam mengelola Bank, agar selalu mengacu atau sesuai dengan tujuan dan strategis bisnis yang telah ditetapkan. Tanggung jawab Dewan Komisaris lainnya adalah melakukan pengawasan terhadap temuan audit intern dan ekstern untuk 
memastikan bahwa semua temuan tersebut telah ditindaklanjuti sesuai dengan komitmen yang telah diberikan oleh Direksi.

Hasil wawancara dengan Direktur Utama pada tanggal 22 September 2013 tentang akuntabilitas mejelaskan bahwa :

"Penerapan prinsip akuntabilitas dalam operasional Bank PD BPR sudah dilaksanakan dengan melakukan pembentukan Dewan Komisaris. Dan melalui pembentukan Dewan Komisaris yang didasarkan pada ketentuan ketentuan GCG tersebut, maka sejak tahun 2012 yang lalu juga telah dilakukan pembentukan komite-komite yaitu Komite Audit, Komite Pemantau Risiko serta Komite Remunerasi \& Nominasi sebagaimana yang diwajibkan, hal ini ditujukan untuk menjamin terlaksanakan prinsip akuntabilitas dalam operasional perusahaan".

Selanjutanya hasil wawancara dengan dewan komisaris Bapak Zulher pada Tanggal 25 September 2012 menjelaskan bahwa :

"Pembentukan komite audit mempunyai tugas pokok untuk membantu tugas komisaris melakukan pengawasan dan memastikan bahwa antara lain semua laporan dan atau temuan hasil audit atas operasional bank yang dilakukan Direksi telah sejalan dengan rencana dan ditindaklanjuti sesuai dengan tata kelola perusahaan yang baik. Selain itu memberikan rekomendasi dalam hal bank akan menunjuk Kantor Akuntan Publik sebagai Auditor Eksternal untuk melakukan fnancial audit. Secara lebih lengkap tugas-tugas dari masing-masing Komite yang bersangkutan telah tercantum dalam Komite Charter-nya masing-masing.

Dalam realisasinya selama tahun 2012 rapat komite-komite diselenggarakan sebanyak 6 (enam) kali, diantaranya telah memberikan rekomendasi kepada Dewan Komisaris dan telah menghasilkan antara lain ; Komite Audit memberikan rekomendasi pemilihan Kantor Akuntan Publik (KAP), dan Surat Dewan Komisaris kepada Direksi tertanggal 20 April 2012 mengenai Penilaian Kinerja Bank PD BPR Sarimadu tahun 2011 dan Saran perbaikan.

Berbeda dengan mekanisme structure governance dari perbankan konvensional dalam hal otoritas pengawasan, karena dalam sistem perbankan BPR terdapat Dewan Pengawas, yang mempunyai tugas untuk senantiasa mengawasi kegiatan usaha bank dan memberikan opini mengenai kemurnian prinsip BPR. Hubungan kerja Dewan Pengawas, Dewan Komisaris dan Direksi adalah hubungan check and balance dengan tujuan akhir untuk kemajuan dan kesehatan Bank PD BPR Sarimadu serta pelaksanaan operasional Bank PD BPR Sarimadu yang senantiasa mematuhi (comply) peraturan dan perundangundangan yang berlaku.

\section{b. Tanggung Jawab (Responsibility)}

Berkaitan dengan prinsip ini, maka seluruh anggota Dewan Komisaris Bank PD BPR Sarimadu telah mengikuti fit and proper test dimaksud dan semuanya telah pula dinyatakan lulus oleh Bank Indonesia sesuai dengan surat 
No.7/7/DpG/DPbS tanggal 27 April 2007 dan No.8/3/DPbS/Rahasia tanggal 1 Juni 2008, dan kemudian telah diangkat oleh Rapat umum Pemegang Saham Tahunan (RUPST) menjadi anggota Dewan Komisaris Bank PB BPR Sarimadu sesuai dengan salinan akta Berita Acara RUPST No.236 tanggal 28 April 2007, untuk jangka waktu 5 (lima) tahun.

Seluruh anggota Dewan Komisaris telah memiliki pengetahuan dan pengalaman yang luas dan cukup banyak di bidang perbankan dan di bidang keuangan, baik di dalam maupun diluar negeri. Hal ini tercantum dan dapat dilihat pada curriculum vitae masing-masing, yang mengambarkan pengalaman mereka dibidang perbankan, pendidikan terakhir, jabatan terakhir dan lain sebagainya.

\section{c. Independensi (Independency)}

Bank perkreditan rakyat harus mampu menghindari dominasi yang tidak wajar oleh stakeholders. Pengelola bank tidak boleh terpengaruh oleh kepentingan sepihak. Bank perkreditan rakyat harus menghindari segala bentuk benturan kepentingan (conflict of interest). Untuk menghindari transaksi yang mengandung benturan kepentingan baik dalam kegiatan operasional/investasi maupun dalam pembiayaan, Bank PD BPR Sarimadu telah mempunyai kebijakan yang antara lain telah di atur dalam Kebijakan Umum Penanaman Dana/Pembiayaan yang pada dasarnya dalam pemberian pembiayaan kepada nasabah dipersyaratkan dalam setiap perjanjian, kerjasama ataupun kontrak baik antara bank dengan nasabah maupun dengan pihak konsultan, akan larangan adanya kaitan kepentingan dengan pihak-pihak tersebut di atas.

Menurut Direktur Utama Bank PD BPR Sariamdu dari hasil wawancara pada Tanggal 22 September 2012 dalam hal independensi sudah melakukan halhal sebagai berikut :

1. Bank menghindari terjadinya dominasi yang tidak wajar oleh stakeholders manapun dan tidak terpengaruh oleh kepentingan sepihak serta terbebas dari benturan kepentingan (conflict of interest).

2. Bank mengambil keputusan secara obyektif dan bebas dari segala tekanan dari pihak manapun.

Dengan demikian maka pada setiap perjanjian pembiayaan ataupun kontrak selalu/wajib dipersyaratkan mencantumkan dalam perjanjian/dan kontrak dimaksud. Ini memberikan arti tidak adanya perlakuan khusus untuk keluarga pegawai bank. Namun dari hasil wawancara dengan komite kredit Bapak Daulai pada Tanggal 7 Oktober 2012, maka diketahui bahwa :

"Proses pembiayaan ataupun pinjaman bagi nasabah sudah ditentukan prosedur dan aturan serta persyaratan yang diperlukan dengan jelas, namun dalam kenyataannya masih ada pihak-pihak tertentu yang mendapat pertimbangan pencairan dana" 
Dalam hal ini bisa kita temukan bahwa masih adanya praktek-praktek diluar ketentuan, menurut peneliti, yang seharusnya setiap permohonan kredit masuk sesuai dengan ketentuan perkreditan yang berlaku sehingga resiko perkreditan dapat dideteksi secara dini, dengan hal ini pelaksanaan prinsip GCG di BPR Sarimadu masih belum dapat berjalan sebagaimana mestinya, sehingga pengelolaan bank belum mampu dilakukan secara efektif dan efisien.

\section{d. Kewajaran (Fairness)}

Dalam aspek kewajaran, menurut hasil wawancara dengan Direktur Utama pada Tanggal 22 September 2012 diketahui bahwa

Manajemen Bank PD BPR Sarimadu sudah melakukan hal-hal sebagai berikut:

1. Bank memperhatikan kepentingan seluruh stakeholders berdasarkan asas kesetaraan dan kewajaran (equal treatment).

2. Bank memberikan kesempatan kepada seluruh stakeholders untuk memberikan masukan dan menyampaikan pendapat bagi kepentingan bank serta mempunyai akses terhadap informasi sesuai dengan prinsip keterbukaan.

Kewajaran disini juga dilihat dari aspek kompensasi yang diterima karyawan. Berdasarkan hasil wawancara dengan salah satu karyawan bank yaitu Bapak Yopi Henriko pada Tanggal 10 Oktober 2012, diketahui bahwa :

"Manajemen sudah memberikan berbagai bentuk kompensasi pada semua pegawai bank sesuai dengan jabatan dan golonganya, namun masih dijumpai adanya ketidakwajaran (keadilan) dalam hal pemberian gaji, seperti tingginya perbedaan gaji antara pimpinan dengan karyawan, adanya kesamaan gaji antara sopir dengan karyawan dan hal lainnya”.

Memang dalam kenyataannya sistem pengajian yang diberlakukan oleh pihak manajemen untuk seluruh karyawan adalah berdasarkan pada jenjang pendidikan, bukan berdasarkan pada beban kerja masing-masing karyawan. Ini menyebabkan adanya rasa ketidak adilan bagi karyawan yang tanggungjawabnya besar dibandingkan dengan mereka yang bekerja dengan beban kerja yang ringan, misalnya adanya kesamaan gaji antara karyawan bagian kredit dengan sopir karena jenjang pendidikan mereka sama. Kondisi ini menyebabkan belum terlaksanakan tata kelola perusahaan yang berdasarkan pada prinsip-prinsip GCG yang berlaku. Dampaknya kinerja perusahaan baik secara finansial maupun secara SDM masih belum dapat dimaksimalkan.

Dari hasil penelitian yang di lakukan oleh penulis maka diperoleh data penyaluran kredit Bank PD BPR Sarimadu yang dari tahun ke tahun mengalami peningkatan yang cukup besar. Dan hal ini disebabkan oleh tingginya tingkat kepercayaan masyarakat terhadap Bank PD BPR Sarimadu oleh karena tata kelola perusahaan yang di terapkan oleh Bank PD BPR Sarimadu berjalan dengan 
cukup baik sehingga berpengaruh terhadap kualitas pelayanan yang diberikan oleh Bank PD BPR Sarimadu yang juga sangat baik.

Kemudian hasil wawancara dan data yang di peroleh penulis, diperoleh informasi, sejak berdirinya Bank PD BPR Sarimadu telah bekerja keras untuk menciptakan tim manajemen yang kuat dan professional serta ditambah lagi dengan diterapkannya prinsip-prinsip good coorporate governance. Bank PD BPR Sarimadu disupervisi oleh dewan komisaris yang di pilih berdasarkan anggota komunitas keuangan.

Berdasarkan hasil penelitian maka diketahui bahwa manajemen eksekutif tertinggi Bank PD BPR Sarimadu adalah Dewan Direksi yang dipimpin oleh Direktur Utama. Bank PD BPR Sarimadu juga memiliki beberapa komite yang menunjang berjalannya operasional perusahaan yaitu Komite Aset dan Liability, Komite Kebijakan Perkreditan, Komite Kredit, Komite Manajemen Resiko, Komite Pengarah Teknologi, dan Komite Pertimbangan Kasus Kepegawaian.

\section{KESIMPULAN}

Dalam melakukan penelitian di Bank PD BPR Sarimadu untuk mengevaluasi prinsip-prinsip Good Corporate Governance. Berdasarkan penelitian tersebut dapat disimpulkan :

1. Penerapan prinsip Transparansi pada Bank PD BPR Sarimadu telah dilakukan dengan sangat baik. Ditandai dengan bank mengungkapkan informasi secara tepat waktu, memadai, jelas, akurat dan dapat diperbandingkan serta dapat diakses oleh stakeholders sesuai dengan haknya dan menerapkan manajemen resiko dalam aktivitas perusahaan.

2. Penerapan prinsip Akuntabilitas pada Bank PD BPR Sarimadu telah dilakukan dengan sangat baik. Ditandai dengan Bank menetapkan tanggung jawab yang jelas dari masing-masing organ bank yang selaras dengan visi, misi sasaran usaha dan strategi bank serta menetapkan kompetensi kepada organ tersebut sesuai tanggung jawab masing-masing.

3. Penerapan Prinsip Pertanggungjawaban pada Bank PD BPR Sarimadu telah dilakukan dengan sangat baik. Ditandai dengan Bank berpegang pada prinsip kehati-hatian (prudential banking practices) dan menjamin kepatuhan terhadap peraturan yang berlaku atas prosedur pemberian kreditnya.

4. Penerapan Prinsip Kewajaran pada Bank PD BPR Sarimadu telah dilakukan dengan sangat baik. Ditandai dengan Bank memberikan kesempatan kepada seluruh stakeholders untuk memberikan masukan dan menyampaikan pendapat bagi kepentingan bank serta mempunyai akses terhadap informasi sesuai dengan prinsip keterbukaan. 
5. Penerapan Prinsip Kemandirian pada Bank PD BPR Sarimadu telah dilakukan dengan sangat baik. Ditandai dengan Bank mengambil keputusan secara obyektif dan bebas dari segala tekanan dari pihak manapun terhadap penyaluran kreditnya.

6. Bank PD BPR Sarimadu berusaha menciptakan iklim usaha yang bersih dan sehat dengan berusaha menekan perilaku fraud pada prosedur pemberian kredit yang di terapkan di perusahaan tersebut dengan menerapkan prinsipprinsip good corporate governance pada aktivitas perusahaan. Dari penelitian ini dapat disimpulkan terdapat pengaruh penerapan prinsipprinsip good corporate governance terhadap kinerja perusahaan. Sejak pertama kali menerapkan prinsip-prinsip Good Corporate Governance sampai saat ini berhasil menekan tingkat resiko kredit dengan tren semakin menurun.

\section{DAFTAR PUSTAKA}

Amrizal. 2008. Penggunaan Hak-hak Pemegang Saham pada Bank BPR. Padang. PT BPR Berok Gunung Pangilun.

Bank, World, 2005, Corporate Governance Country Assessment: Republic of Indonesia, Jakarta.

Bank Indonesia, 2008, Booklet Perbankan Indonesia, Direktorat Perizinan dan Informasi Pebankan.

BEI NEWS. 2004. Corporate Governance Perbankan di Indonesia "Menata Bank dengan Corporate Governance". BEI NEWS Edisi 19 Tahun V, MaretApril 2004.

Bungin, 2003, Analisis Data Penelitian Kualitatif, PT. Rajagrafido Persada: Jakarta.

Chandra, Aditiawan. 2006. Perlunya Komisaris Independen Dalam Mewujudkan Good Corporate Governance di Korporasi.

Darmawati. Dkk. Hubungan GCG dan Kinerja Perusahaan. Dalam JRAI Vol. 8. 1 Januari 2005. Hal 65-81.

Effendi, M. Arief 2005. Peranan Komite Audit dalam Meningkatkan Kinerja Perusahaan Jurnal Akuntansi Pemerintah, Vol. 1 No. 1, Mei 2005, Him. 51-57.

Effendi, Muh Arief. 2007. “CSR melalui Community Development”. Dalam Suara Katya Online, 7 November 2007. Jakarta.

Fadjriah, Siti Ch. 2005. "Manfaat dan Kendala Penerapan GCG Perbankan". Dalam Kompas, 27 April 2005. Jakarta.

Faisal, 2004, Analisis Agency Cost, Struktur Kepemilikan dan Mekanisme Corporate Governance, Simposium nasional VII, Ikatan Akuntansi Indonesia.

Forum for Corporate Governance in Indonesis (FCGI), Tata Kelola Perusahaan Jilid 1 EDISI ke-4, PricewaterhouseCopers dan FCGI, Jakarta: 2005. 
Ghufron, M, 2008, “69,3\%Bank Tak Patuhi GCG”, www.jurnalnasional.com@ 2008, PT. Media Nusantara Pradana

Gunadi, Eddie M. 2004. Corprate Governance: Tugas dan Tanggung Jawat? Komite Audit, Forum for Corporate Governance in Indonesia (FCGI).

Herry. Dkk. 2006. "Studi Peningkatan Peran BPR dalam Pembiayaan Usaha Mikro Kecil (UMK) di Sumatera Barat”. Dalam Journal CBR Unand BPR.pdf.

Indaryanto, Khomsiyah G., dkk. 2004. Komitmen Menegakkan Good Corporate Governance. The IICG, Jakarta.

Kalbers, Lawrence P. \& Forgathy, Timothy J. : “Audit Committee Effectiveness : An Empirical Investigation of the Contribution of Power". Auditing A Journal of Practice \& Theory, Vol. 12, No. 1, Spring, 1993.

Kusumawati, Dwi Novita dan Bambar.g Riyanto Ls. 2005. Corporate Governance dan Kinerja: Analisis Pengaruh Compliance Reporting dan Struktur Dewan terhadap Kinerja. SNA VIII Sole, 15 - 16 September 2005. (Universitas Gadjah Mada)

Majidah, 2004, Manfaat Penerapan Prinsip-Prinsip Good Corporate Governance Terhadap Kinerja Keuangan Perusahaan Perusahaan. Skripsi Sarjana (tidak dipublikasikan). Bandung: Fakultas Ekonomi Universitas Widyatama. 2008

Mangkunegara, Anwar Prabu. 2005. Evaluasi Kinerja SDM. Cetakan Pertama. PT. Refika Aditama, Bandung.

Marsa, Diyana. 2006. "Evaluasi Perusahaan Dalam Rangka Penerapan Good Corporate Governance Pada PT. PLN (Persero)". Skripsi: Padang: Fakultas Ekonomi Universitas Andalas.

Moeljono, Djokosantoso, 2005, "Good Corporate Culture Sebagai Inti Dari Good Corporate Governance”, Elex Media Komputindo, Jakarta.

Moh, Wahyudin, 2008, Good Corporate Governance pada badan Usaha Manufaktur, Perbankan, dan Jasa Keuangan Lainnya, Alfabeta, Bandung.

Muh. Arief Ujiyantho dan Bambang Agus Pramuka. Mekanisme CorporateGovernance, Manajemen Laba dan Kinerja Keuangan. Makalah SNA X. 2007

Noerhadi. Good Corporate Governance Mencegah Krisis Ekonomi Kedua. Business News 6669/28-09-2001.

Nyoman Tjager, 23-24 Jan 2003, GCG Indonesia Rendah, Seminar nasional $G C G$, Bali.

Peraturan Bank Indonesia No.5/8/PBI/2003, Penerapan Manajemen Resiko Bagi Bank Umum, Indonesia.

Peraturan Bank Indonesia No. 8/4/PBI/2006, Pelaksanaan Good Corporate Governance bagi Bank Umum, Indonesia.

Pratolo, Suryo. 2007. GCG dan Kinerja BUMN: Aspek Audit Manajemen dan Pengendalian Intern sebagai Variabel Eksogen serta Tinjauannya pada Jenis Perusahaan. SNA X, Unhas Makasar, 26-28 Juli 2007. (FE. Universitas Muhammadiyah Yogyakarta). 
Saputra, Irvan. 2003. Analisa Kemungkinan Penerapan Good Corporate Governance pada Bank Nagari Sumatera Barat. Skripsi: Padang: Fakultas Ekonomi Universitas Andalas.

Sherman, D. dan Arman Zein. 2008. Pentingnya Penerapan GCG terhadap Kinerja BPR. Padang.

Soegiharto, 2005. Peran Akuntan dalam Menegakkan Good Corpoate Governance. Dalam Majalah Auditor. No. 18

Sudharmono, Johny. 2004. Be G2C Good Governed Company. PT Elex Media Komputindo. Jakarta.

Sukrisno, Agoes. 2005. Penerapan GCG Pada Perguruan Tinggi. Dalam Majalah Auditor, No. 18

Sulistiyanto, H Sri dan S Meniek Prapti. 2003. Good Corporate Governance: Bisakah meningkatkan Kepercayaan Masyarakat?. Jurnal "Ekonomi dan Bisnis-Ekobis”, VOL.4 No.l Januari 2003.

Syakhroza, Akhmad 2003. "Best Practices Corporate Governance dalam konteks Kondisi Lokal Perbankan Indonesia”. Manajemeu Usahawan Indonesia. No. 06 Th. 32, Juni. 